\title{
Low iron mitigates viral survival: insights from evolution, genetics, and pandemics - a review of current hypothesis
}

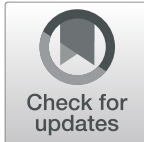

\author{
Rahma Menshawey ${ }^{1 *}$ DD, Esraa Menshawey ${ }^{1}$, Ayman H. K. Alserr ${ }^{2}$ and Antoine Fakhry Abdelmassih ${ }^{3}$
}

\begin{abstract}
Background: Upon re-examination of our human history, evolutionary perspectives, and genetics, a prevailing iron deficiency phenotype appears to have evolved to protect the human race from extinction.

Body: In this review, we summarize the evolutionary and genetic perspectives pointing towards the hypothesis that low iron mitigates infection. The presence of infection promotes the generation of resistance alleles, and there are some evolutionary and genetic clues that suggest the presence of an iron deficiency phenotype that may have developed to protect against infection. Examples include the relative paucity of iron overload genes given the essential role of iron, as well as the persistence of iron deficiency among populations in spite of public health efforts to treat it. Additional examination of geographic areas with severe iron deficiency in the setting of pandemics including H1N1, SARS, and COVID-19 reveals that areas with higher prevalence of iron deficiency are less affected. RNA viruses have several evolutionary adaptations which suggest their absolute need for iron, and this dependency may be exploited during treatment.
\end{abstract}

Conclusion: RNA viruses pose a unique challenge to modern healthcare, with an average of 2-3 new pathogens being discovered yearly. Their overarching requirements for iron, along with human evolutionary and genetic adaptations which favored an iron deficiency phenotype, ultimately suggest the potential need for iron control in these infections.

Keywords: Iron deficiency anemia, RNA viruses, COVID-19, Hyperferritinemia, Hepcidin, Ferroptosis

\section{Background}

Ancient stars in their death throes spat out atoms like iron which this universe had never known. ... Now the iron of old nova coughing's vivifies the redness of our blood. Howard Bloom

Coronavirus Disease 2019 (COVID-19) is a viral infection caused by the newly discovered Severe Acute Respiratory Syndrome Coronavirus 2 (SARS-Cov-2). It was first discovered in the city of Wuhan, China, in

\footnotetext{
* Correspondence: rahma.a.abdelmohsen@students.kasralainy.edu.eg

${ }^{1}$ Faculty of Medicine, Kasr al Ainy, Cairo University, Geziret Elroda, Manial,

Cairo 11562, Egypt

Full list of author information is available at the end of the article
}

December 2019, and by March 11, 2020, the World Health Organization (WHO) declared it as a global health emergency [1]. Recent findings and lab data suggests that COVID-19 falls within the spectrum of hyperferritinemia syndromes given the shared manifestations of macrophage activation syndrome (MAS), multiple organ dysfunction (MOD), and septic shock [2]. The nature of this ribonucleic acid (RNA) virus, along with findings of hyperferritinemia [3], may be responsible for the resulting increase in intracellular iron, which is the main trigger for ferroptosis within cells. These findings suggest an underlying role of iron in the pathogenesis of COVID-19.

Advancements in our civilization may have increased our risk to infections and disease, as well as stressed our

\section{Springer Open}

(๑) The Author(s). 2020 Open Access This article is licensed under a Creative Commons Attribution 4.0 International License, which permits use, sharing, adaptation, distribution and reproduction in any medium or format, as long as you give appropriate credit to the original author(s) and the source, provide a link to the Creative Commons licence, and indicate if changes were made. The images or other third party material in this article are included in the article's Creative Commons licence, unless indicated otherwise in a credit line to the material. If material is not included in the article's Creative Commons licence and your intended use is not permitted by statutory regulation or exceeds the permitted use, you will need to obtain permission directly from the copyright holder. To view a copy of this licence, visit http://creativecommons.org/licenses/by/4.0/. 
survival fitness. Overcrowding, domestication of animals, and the agrarian revolution may have all played a role in the development of a prevailing protective iron deficiency phenotype, which may have increased our resistance as a species to acute infections and epidemics [4]. In this review, using insights from evolution and genetics, we summarize the hypothesis that low iron may mitigate infection, as well as the potential benefits of iron control in the setting of infections, such as the current pandemic.

\section{Main text}

\section{Iron, iron deficiency, anemia, and infection i. Iron's role in infection}

Iron is a vital element required in the internal processes and cellular operations of nearly all multi-cellular organisms [5]. Uniquely, bacteria, fungi, and some viruses have developed methods to extract iron from their hosts [6]. Some viruses infect iron-acquiring cells by binding to transferrin receptor type 1 , while other viruses target the Human Homeostatic Iron regulator Protein (HFE) genes and hepcidin, with the end goal of inducing iron overload on a cellular level to promote their survival and replication [7]. For example, the cytomegalovirus (CMV) interferes with the Major Histocompatibility Complex (MHC) class I proteins causing the proteosomal degradation of HFE, reversing the hepcidin effect of reducing cellular iron uptake, allowing cells which they infect to become overloaded with iron [8].

In a study regarding the correlation between iron levels and viral load, Chang et al. found that there was reduced virulence within iron deficient cells [9]. It was further demonstrated that iron-chelation benefits the host by reducing the amount of viral nucleic acids and proteins, which in turn decreases viral replication and release. Additionally, low iron levels could downregulate the expression of adhesion molecules required for viral attachment and internalization [911]. Notably, iron intake that exceeds the body's needs may promote the proliferation of pathogens, while some evidence suggests that a state of hypoferremia can be protective in endemic areas. Dietary iron restriction may protect against infection in settings of high transmission or morbidity [12]. One study suggests that prophylactic daily supplementation of iron and folic acid, with or without zinc, showed no significant differences in attack rates of respiratory infection, dysentery, or diarrhea. Interestingly, this study had originally hypothesized that iron supplementation would mitigate mortality risk in their cohort of Nepali children with iron deficiency anemia, but the rates of mortality and morbidity did not differ between treatment and placebo groups [13]. This study suggests that the presence of concurrent malnutrition (i.e., protein energy malnutrition) disorders limit the effectiveness of iron therapy in the setting of iron deficiency anemia (IDA), while other studies suggest that the resistance to iron supplementation in the setting of anemia may be due to genetic variations. When controlling for the presence of chronic illness and malabsorption diseases in patients with IDA, analysis revealed that the presence of genetic variants (T495M and P555S) is responsible for non-response to parenteral iron therapy $[14,15]$. Contrastingly, cell-mediated immunity is affected by iron deficiency, as demonstrated by Das et al. who found that patients with IDA had significantly lower levels of $\mathrm{CD} 4+\mathrm{T}$ cells $(P<0.05)$, as well as a declining CD4 to CD8 cell ratio. Cell-mediated immunity (CMI) was improved with iron supplementation for 3 months [16]. The goal remains in finding the optimal iron status in the setting of infection [17] and finding the trade off point between its effects on immunity in the setting of infection. As suggested by Wander et al., a compromise will exist between the effects of hypoferremia on CMI, and the need for resisting certain infections, and local disease ecology [12].

\section{ii. Iron deficiency anemia, females, and COVID-19 infection}

IDA is a type of anemia defined as inadequate tissue oxygenation caused by abnormal red blood cells as a result of a defective iron state, which is prevalent worldwide. Females are more commonly affected owing to the chronic blood loss during menstruation and pregnancy [18]. According to the WHO, global anemia prevalence is $30.2 \%$ (95\% CI $28.7-31.6$ )/468 million (95\% CI $446-$ 491) among non-pregnant women of reproductive age (WRA). Of the number of individuals affected by anemia worldwide, $29 \%$ were non-pregnant WRA, while $16 \%$ of those affected were males. The highest prevalence was found in Africa (47.5\%) and South East Asia (45.7\%), while the lowest prevalence was in the Americas (17.8\%) $[19,20]$. Studies suggest that many intracellular microorganisms, such as plasmodia and mycobacteria, are enhanced by iron therapy; while there appears to be a decreased susceptibility to malaria-related illness [21, 22], human immunodeficiency virus (HIV) [23, 24], and tuberculosis (TB) $[25,26]$ in patients with IDA. Oral iron supplementation has been associated with increased risk of infection and morbidity. In fact, treatment of anemia in malaria endemic areas is not recommended without prophylaxis for malaria [24, 27]. The right balance must be found between dose and timing of intervention in areas with endemic infectious disease [28]. Given that IDA has higher prevalence among females worldwide, this deficiency may have a potential protective factor for females in the setting of COVID-19 infection.

COVID-19 patient data suggests a decreased risk of infection and decreased risk of poor outcome (either intensive care unit (ICU) admission or mortality) in females [29-31]. Sharma et al. outlined the differences in mortality between sexes during the COVID-19 pandemic, and concluded that males were more likely to 
develop severe disease, and had higher mortality and case fatality ratio compared to females [32]. Reports from Italy have shown higher death rates for males compared to females across all age groups, with a male to female death ratio of 80 to 20\% [33]. Moreover, SARS$\mathrm{COV}$, as well as Middle Eastern Respiratory Syndrome (MERS)-COV, also affected more males than females [34]. Mortality appears to be related to the presence of risk factors including cardiovascular disease, which have higher occurrence in men. It is posited that females are more protected than males owing to the role of estrogen and the $\mathrm{X}$ chromosome on the immune system, as well as social behavioral differences between males and females that favor female overall health, such as willingness to seek preventative care [32, 35].

In China, an interesting observation was made, in that in pregnant females, no increased risk for COVID-19 was observed. In another study, $92 \%$ presented with mild disease and only $8 \%$ (9 patients) had severe hypoxemia. Moreover, of those 9 patients with severe disease, 6 of them developed this only after delivery [36]. This observation warrants more robust research. Reduced iron availability in pregnant females may be protective. The prevalence of anemia in pregnant females may range from anywhere between $35-75 \%$ in developing countries and $18 \%$ in developed countries [37, 38]. During fetal development, iron being shunted from the mother to the fetus may result in IDA, which may be a protective factor for pregnant females in the setting of COVID-19. The placenta itself retains approximately $90 \mathrm{mg}$ of iron for its own functions, as well as shunts $270 \mathrm{mg}$ of iron to the fetus, throughout the second and third trimesters $[39,40]$.

In Figs. 1 and 2, we have mapped out the world wide occurrence of IDA in women of reproductive age (WRA), which is considered all women of child bearing age between the ages of 15 and 49 years (menarche till menopause) (data retrieved from WHO survey), as well as case fatality rate (CFR) of COVID-19 infection (from data retrieved on June 2, 2020) worldwide. Stark and interesting contrasts can be noticed immediately. The great majority of Sub-Saharan Africa (SSA), which consist of all African countries geographically south of the Sahara desert, reports a CFR of $<5 \%$, while having the highest known prevalence of IDA. Interesting juxtapositions are seen in neighboring countries, for example, $\mathrm{Pa}$ pua New Guinea IDA prevalence $>40 \%$ versus Indonesia CFR $>5 \%$, the major affection of South America with a CFR $>5 \%$ except for Peru and Guyana, which have a severe IDA prevalence of $>40 \%$, and the highest concentration of countries with CFR $>10 \%$ in European countries with generally mild IDA prevalence, and this contrast is also seen in America and Canada. These observations suggest a potential connection between IDA prevalence and CFR that needs more evidence to prove. Interestingly, countries with the highest prevalence of IDA seem to be more protected, thus implying that IDA works through a sort of "herd immunity" to protect endemic areas from acute infection, which may also explain why there are lower infection and mortality rates reported in areas like that of SSA.

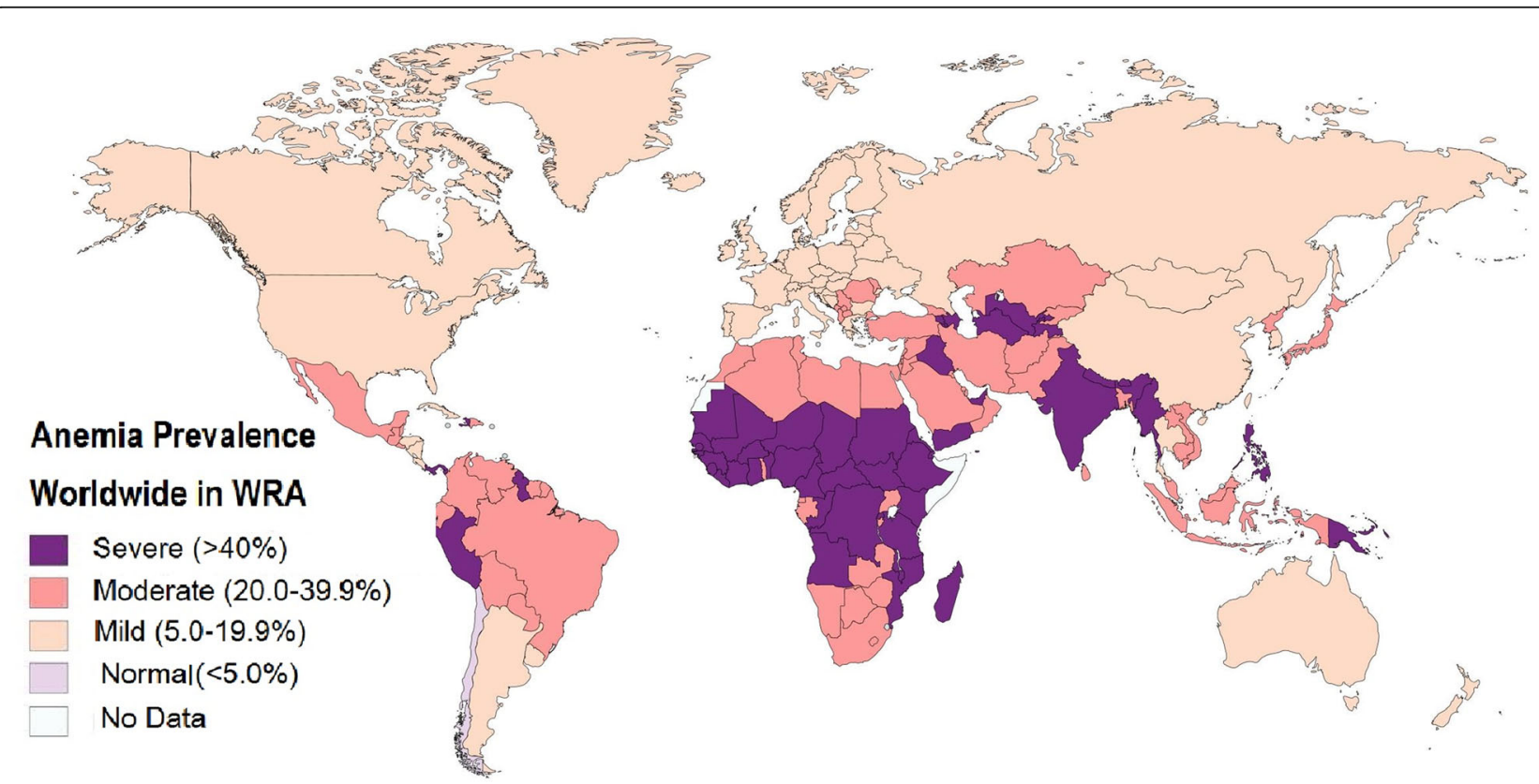

Fig. 1 Anemia prevalence worldwide in women of reproductive age. The highest prevalence is seen in Sub-Saharan Africa (SSA), Eastern Mediterranean, and South East Asia. The lowest prevalence is in the Americas. Data source: WHO 


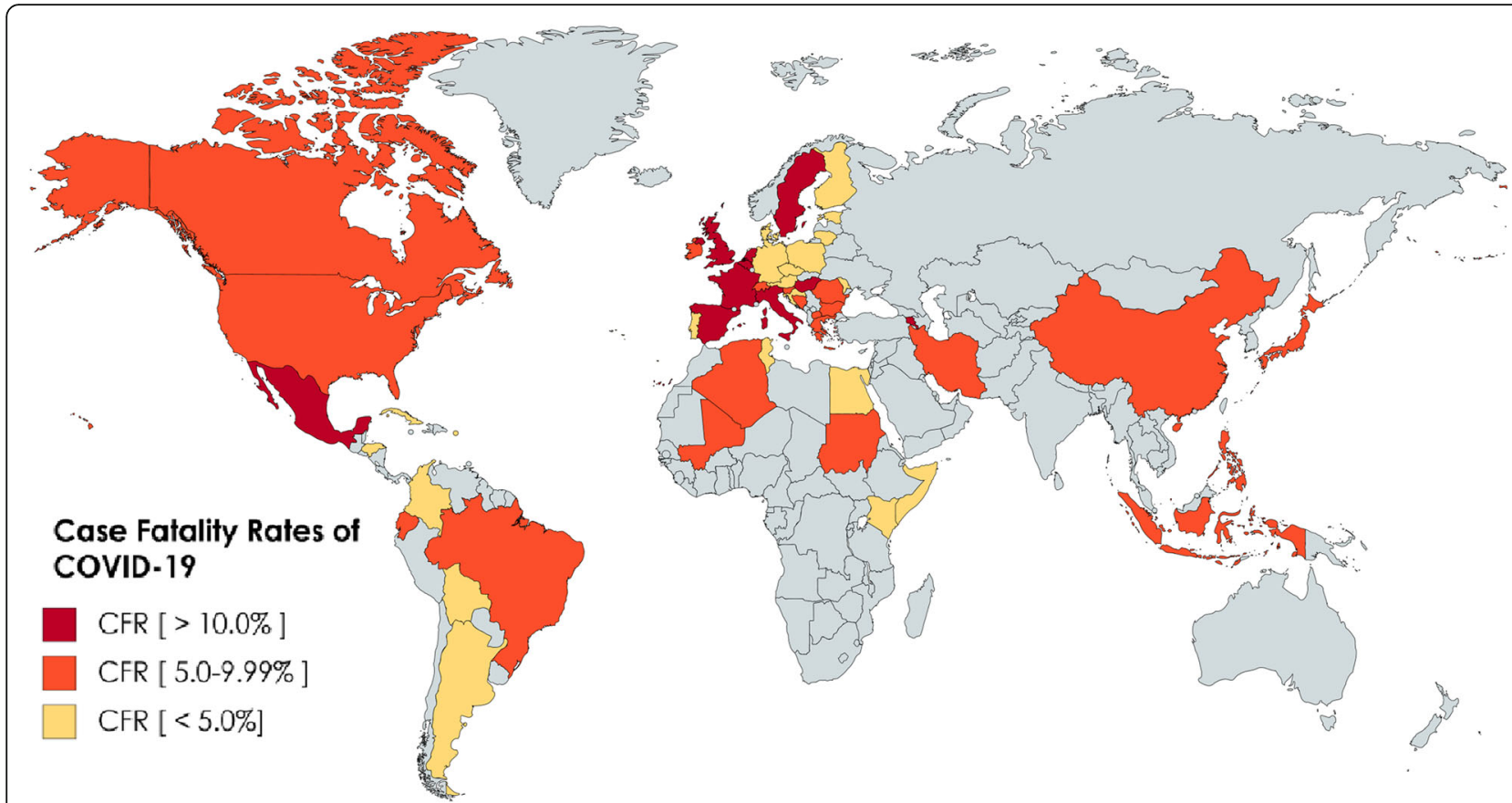

Fig. 2 Case Fatality Rate world map, based on data accessed on June 3, 2020. CFR is defined as the number of deaths divided by the number of incident patients within a specified time. CFR is least affected by reporting bias but maybe underestimated by time lag bias due to diagnosing and reporting cases, and the assumption that all cases have been reported, while it may be overestimated by the definition of a case, either confirmed or closed. This map depicts the CFR so far. The highest CFR (> 10\%) is reported in Belgium (16.21\%), France (15.47\%), Italy (14.35\%), Hungary (13.54\%), the Netherlands, Sweden (11.64\%), Spain (11.32\%), and Mexico (10.58\%). Comparing this map to the IDA prevalence Map in Fig. 1, a stark contrast is seen. Countries with high IDA prevalence have yet to report CFR $>3 \%$. This includes the majority of SSA, excluding Kenya and Mali, as well the South East Asia. Meanwhile, countries with mild anemia prevalence appear to be reporting much higher CFR. There appears to be a connection between severe anemia and lesser CFR, bolstering the notion that the anemic defense is an evolutionary response to acute infection in the endemic setting, a chronic anemia "herd immunity" of sorts that may protect populations rather than a case by case basis

A systematic analysis of national surveys regarding IDA prevalence among WRA revealed that African countries had the highest prevalence of IDA, including Côte d'Ivoire (49.9\%) and Sierra Leone (44.8\%) [41]. Of concern is the health care system status and the economic factors in poorer countries of SSA; it is unclear should a connection between COVID-19 and IDA protection exist, how robust this protection would be in the face of under developed healthcare systems and economies. There is evidence that suggests some form of economic and health care instability in SSA that occurred in the aftermath of the Ebola outbreak [42, 43]. Additionally, the African continent appears to be struggling with limited testing capacity. The COVID-19 gold standard test is the nucleic acid-based real-time quantitative polymerase chain reaction (PCR), which is expensive and requires expertise. Even the alternative serological tests with low sensitivity are more available in high income countries. African countries also suffer from low staffing, and inadequate referral systems, which may explain the lower numbers of reported cases. One alternative explanation is that previous pandemics may have actually better prepared African countries in the handling of infectious diseases in the form of swift lockdowns, and the setting up of task forces for pandemic response. Additionally, Africa shows low importation risk, with the highest risk coming only out of Egypt, Algeria, and South Africa [44]. Lastly, Africa's younger population may explain its lower infection rates, with the median age of Africa being 19.4 years, as compared to 38 and 40 in the USA and Europe, respectively [44, 45].

These observations suggest that it is not the severity of anemia (which COVID-19 patients with severe hypoxemia were observed to have more profound hypoferremia [46]), but rather the severity of the prevalence of anemia that is potentially protective, as counties with mild prevalence show a CFR exceeding $5 \%$, as well as the overall distribution given a geographical range. COVID-19 has yet to deeply infect SSA as the geographical range of IDA prevalence is tightly woven in this area. Figures 3 and 4 also depict worldwide affection of the H1N1 virus, and the SARS 2002 epidemic, notably IDA prevalent areas that were minimally affected.

It is suggested that during epidemics with high mortality rates, iron deficiency decreased death and improved 


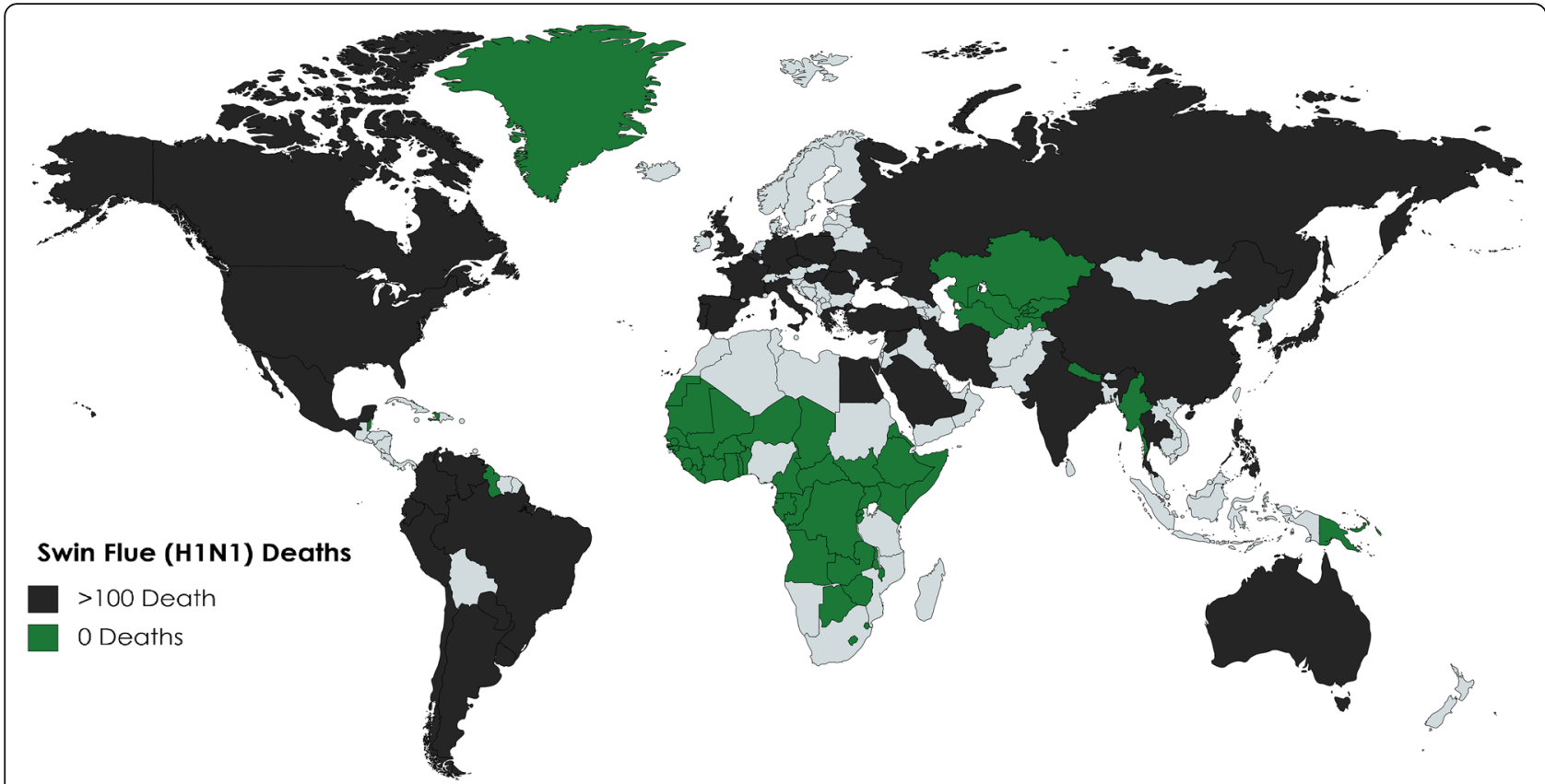

Fig. 3 Depicted here are the recorded deaths of the 2009 Swine Flu H1N1 epidemic (source: ECDC). Countries in black suffered more than 100 deaths; deaths were highest in the USA, Brazil, India, and Mexico (> 1000). Countries in green reported no deaths owing to H1N1. Yet again, the highest prevalence IDA countries were very nearly all protected from $\mathrm{H} 1 \mathrm{~N} 1$ fatalities

survival odds by "affecting the outcome of bacterial superinfection." This increases for each epidemic faced by a single generation, resulting in an "increased overall fitness of the iron deficient individual" [4]. Additionally, Denic et al. point out that struggles against deadly infections, such as the plague and malaria, may have exerted enough evolutionary pressures to increase the prevalence of an iron deficiency phenotype [4].

\section{Iron from an evolutionary perspective}

From an evolutionary perspective, despite advances in public health to deal with IDA, such as the availability of iron supplements, improved nutrition, and fortification of foods, IDA remains a persistent issue. It is suggested that an iron deficiency phenotype had developed over years of evolution and survived under selection pressures, given the changes to human culture that lead to overcrowding, disease, and agriculture-related iron deficiency diets. It is posited that a failure to adapt to iron deficiency, both genetically and culturally, led to the prevalence of an iron deficiency phenotype.

\section{Female menstruation}

Denic et al. point towards the excessive menstruation among human females when compared to other primates, such as gorillas and orangutans. Menstruation is the main cause of IDA in females overall. One theory suggests that excessive menstruation in human females was adapted to enhance iron loss. A clear distinction between the herbivore diet of non-human primates and the meat-eating human primate would suggest that a heavier menstruation was adapted to relieve the body of potential excess iron through diet (iron from meat is also more readily available). The origin and purpose of female menstruation is a matter of debate. Evolutionary insights are summarized in Fig. 5.

\section{The rarity of human homeostatic iron regulator protein mutations}

An additional clue for the evolutionary need for iron deficiency lies in the relative paucity of hemochromatosis genes. Given the essential need for iron in human development, the question becomes why are iron overload diseases less common than iron deficiency phenotypes? The frequency of mutations in the HFE gene worldwide is very low, where in non-European populations the frequency of $\mathrm{C} 28 \mathrm{Y}$ and $\mathrm{H} 36 \mathrm{D}$ allele mutations is $<1 \%$ and $4 \%$, respectively [47]. HFE lies in close proximity to genes involved in immune defense, being located within the major histocompatibility complex (MHC) 1, suggesting a non-immune related role of iron against infection. Hereditary hemochromatosis $(\mathrm{HH})$ was found to affect the immune system as follows: (1) decreased number of Natural Killer $\mathrm{T}$ cells (NKT) relating to serum ferritin and transferrin saturation, (2) abnormalities between CD8+ T cell pool, (3) iron-related phenotypic changes in surface expression of molecules on T lymphocytes, (4) lower numbers of circulating and hepatic CD8 cells, and 


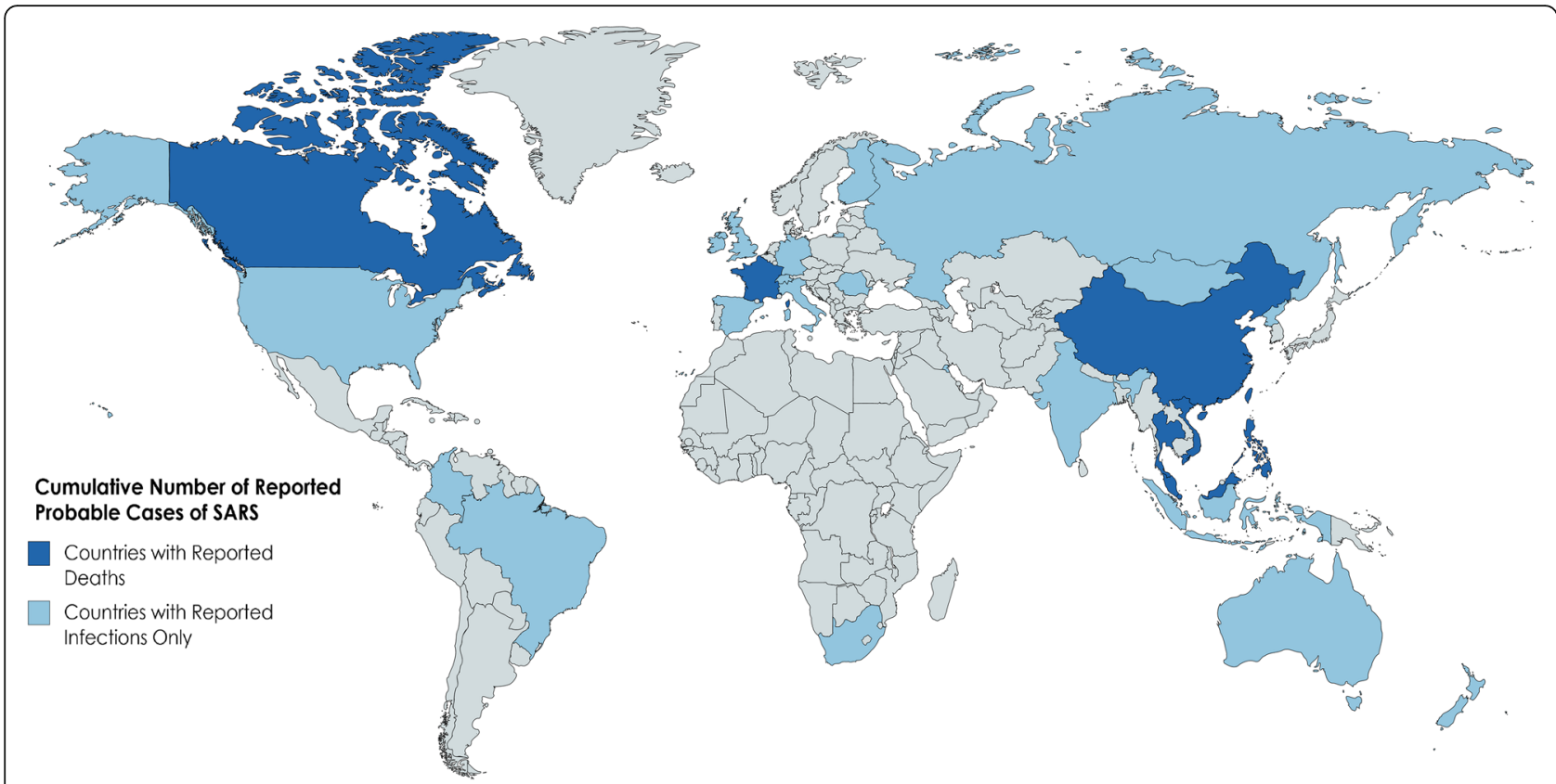

Fig. 4 Cumulative number of reported probable cases of SARS based on data from Nov 1, 2002, to July 11, 2003 (source: WHO). Depicted here are countries with reported deaths and infections versus reported infections and no deaths. Countries of high prevalence IDA (see Fig. 1) in SSA were relatively virus free

Prevalence of an IDA phenotype that developed

under the stress years of

infection to increase odds of

survival against iron

dependent pathogens

The relative paucity of iron overload conditions and HFE

mutations, as well as links

between iron control and immune function

The endurance of cultural norms that have an adaptive role in lowering iron levels such as vegetarianism and the consumption of tea and coffee

Fig. 5 Several evolutionary and social adaptations support the theory that a low iron state may have evolved to mitigate infection. These include the prevalenve of an IDA phenotype that may have protected against iron dependant pathogens, the excessive mentruation oberved in female human primates, the paucity of iron overload conditions, the selection pressures put in place by agriculture and the domestication of animals which would have exposed early humans to novel pathogens, changes in human diet, as well as the persistance of age old blood letting procedures prescribed in ancient medical therapies for the treatment of febrile illness
(5) diminished cytotoxic activities of Cytotoxic $\mathrm{T}$ lymphocytes (CTL) [48-50].

HFE immunologic role further bolsters the theory of the connection between iron control and the adaptive immune response to pathogens, and implies a regulatory connection between iron metabolism and the immune system. Furthermore, some viruses such as the CMV directly induce degradation of HFE genes to promote iron overload states on a cellular level, providing ample iron needed as its resource [51, 52]. From an evolutionary standpoint, not only has an iron deficiency phenotype prevailed, but also mutations that would increase iron overload states are rare, and have detrimental effects on the immune system.

\section{Other genetic considerations}

One theory suggests that the presence of pathogens, especially those with high mortality, trigger natural selection in humans to increase resistance alleles, and decrease susceptibility alleles. This may explain the prevalence of anemic conditions throughout geographical or ethnic regions that are targeted by iron-acquiring pathogens. In their paper "The legacy of past pandemics: common human mutations that protect against infectious disease," Pittman et al. stated that epidemiology of resistant populations and geographical patterns prove that human genetic variations can alter "infection susceptibility and outcomes" [53]. Additionally, sequencing has shown that pathogen-driven selection targets specific 
loci to increase the alleles for disease, which lends credence to the hypothesis that the maintenance of disease is owed to past pathogen-selective pressures. Background demography is the strongest factor influencing these variations $[54,55]$.

One clue that supports this comes from a recent finding that respiratory infections trigger hepcidin-meditated blockade of iron absorption in Africans. Prentice et al. discovered that in African children, a hepcidindependent physiological block of iron absorption was occurring to the effect of reducing their risk of respiratory infection [56]. An unusually large bolus of iron would be needed to overcome this block, though not without iatrogenic harm [57]. This is another clue to the hypothesis that low iron mitigates infection as a result of infection-related selective pressures. In a recent study, patients with sickle cell disease were found to have low morbidity and mortality with COVID-19. Though these patients were perceived to be high risk, they were "somehow protected from severe symptoms and complications of COVID-19 infection" [58]. One hundred percent of their cohort was African-American, and had anemia with a mean hemoglobin of $7.8 \mathrm{~g} / \mathrm{dL}$. It was unclear whether hemoglobin $(\mathrm{Hb}) \mathrm{F}, \mathrm{HbS}$, or medications were providing a protective effect. Iron deficiency is a common finding in patients with sickle cell disease [59], mostly due to intravascular hemolysis causing urinary loss of iron [60]. Perhaps their low iron status protected against the detrimental hyperinflammatory response to COVID-19 infection, as suggested in this hypothesis.

Other examples include hypoferremia and malaria. The malaria parasite is highly dependent on a small pool of labile iron in the cytoplasm, and is susceptible to nutritional influences that affect this compartment [57].

Among global populations, there are known differences between genetic variations involving iron imbalance, though there is a call for further investigation of these genetic influences among Sub-Saharan Africans due to a significant lack of data [61].

There are other examples of genetic variants developed to protect against past pandemics, which influence infectious diseases today. The best described example is the CCR5- $\Delta 32$ allele, believed to have developed 700 years ago in response to Yersinia pestis, the causative organism of the bubonic plague. Individuals that are homozygous for this allele are totally resistant to HIV $[62,63]$. The presence of resistance alleles confers some evolutionary advantages. The question remains why these alleles are not fixed. This may be explained by the heterozygous advantage which balances the selection; a notable example being the sickle cell trait which lacks sickle cell disease while protected from malaria. Another reason is simply that the selective pressures fluctuate as pandemics end and new pathogens are introduced, where the previous genetic variant may not be advantageous, or even disadvantageous. For example, while CCR5- $\Delta 32$ allele confers immunity to HIV, on the other hand, it increases the risk for West Nile virus infection [64]. Additionally, several generations are needed for the fixation of resistance alleles.

This may explain the contrast between Black Africans who, according this hypothesis, are perhaps protected against COVID-19, as compared to African-Americans who are currently among the high risk groups for COVID-19 infection. One study suggests that AfricanAmericans are at a markedly high risk of infection "that is not fully explained by characteristics of the environment and pre-existing conditions in the population"; perhaps, a genetic influence is responsible [65]. Abdelmassih et al. have outlined the use of a single-cell sequencing in COVID-19. A connection was found between genetic and immune cellular mechanism underlying COVID-19. Substantial variation was found in the rate and severity by which it impacts different demographic groups; predilection was found towards AfricanAmericans [66].

Finally, while resistance alleles may protect against infectious disease, they may increase autoimmune and chronic disease. One example involves coding changes on the APOL1 gene, which is protective against African sleeping sickness caused by Trypanosoma brucei rhodesiense. This same coding variant increases the risk of focal segmental glomerulo-sclerosis and non-diabetic end-stage renal disease in African-Americans [67].

\section{iv. Iron, RNA viruses, and the RNA world hypothesis}

The RNA world hypothesis posits that, in the evolutionary history of life, it is the RNA molecule that is the origin of life on earth. RNA possesses a multitude of characteristics that befit this theory, such as, its ability to store, transmit, and self-replicate genetic information and its ability to catalyze simple reactions including peptide bonds to form protein $[68,69]$. Evidence to this theory further lies in the presence of viroids which are extremely small (246-467 nucelobases), circular, singlestranded, non-coding RNA plant pathogens [70]. Diener proposed that these viroids represent relics of the RNA world [71]. Recently, Forterre theorized, in his "three viruses; three domains" hypothesis, that the last universal common ancestor is an RNA virus [72]. CarrascoHernandez et al. recently suggested that RNA viruses are the next likely candidates for upcoming global epidemics. Modern medical technology appears to be particularly challenged by RNA viruses, owing to their rapid adaptive rates and biologic diversity [73]. Studies have identified RNA viruses as the primary cause of all emerging infectious diseases, with a rate of 2-3 novel viruses being discovered yearly [31]. The RNA viral genome has 
been shown to adapt effectively under selective pressures, owing to their high mutation rates [74]. Many RNA viruses also lack proofreading ability, apparently benefiting from mutability. Coronaviruses are uniquely equipped with a proofreading ability, shown in their Nsp14 protein which functions as a $3^{\prime} 5^{\prime}$ exoribonuclease [73]. Mutations within the RNA viral genome can be of great risk to the survival of any virus. Owing to the high fidelity to their code, a single-point mutation can greatly decrease the efficiency of the replication process. In simple terms, each mutation may increase the number of either unviable or viable virions. If the number of unviable virions exceeds the viable ones, the "point of fidelity of equilibrium" tips. Now, loyalty to its genetic code will be to the detriment of the fitness and survival of the entire species, leading to the so called mutational meltdown [73]. Given the unusually long genome of the coronaviruses, and the understanding that the longer the genome the greater the risk of mutation accumulations per replication, it is clear that the presence of the proofreader is of paramount significance to the survival of this species [75]. It is suggested that coronaviruses selectively turn on or off their proofreading ability, allowing them to rapidly adapt to evolutionary stresses effectively, acquiring the right mutations at the right time to ensure adaptability without loss of fidelity to their code and loss of fitness for survival [76].

In his paper titled "Regulation by Iron; RNA Rules the Rust," Kadner mentions that iron is both a challenge to obtain and maintain, as well as the concern involving production of dangerous reactive oxygen species [77]. Therefore, pathogens must obtain iron given its necessity for their survival, as well as find ways to protect themselves from its adverse effects. RNA appears to affect the expression of genes involved in iron metabolism, as was discovered in the sRNA of $V$. cholera and $E$. coli $[78,79]$. Fur proteins are found in many microorganisms, such as E. coli, $C$. diphtheria, and $P$. aeruginosa, which have a role in iron-dependent repression. There are two possible settings: (1) in the setting of limited iron, the fur protein is inactive as a repressor and sRNA RhyB is depressed (which is responsible for increasing the turnover of iron-containing proteins that also protect the pathogen from iron damage, such as superoxide dismutase), resulting in increased affinity of iron uptake, and (2) in the setting of excess iron, Fe- Fur binding causes increased expression of iron-containing proteins as well as storage proteins. Furthermore, Fur-binding sites overlap promoter sites for RNA polymerase. These findings suggest the absolute need of iron by RNA and RNA pathogens. RNA pathogens have evolved the perfect mechanisms in dealing with iron-dependent survival challenges [77]. Coronavirus replication was found to be suboptimal in iron-depleted cells. Aconitase is an iron- dependent coronavirus replication protein, whose function was blocked by the use of iron chelators. These findings suggest the iron dependency of coronaviruses [80-82].

\section{The overarching connection of iron to COVID-19 i. Hyperferritinemia syndrome and COVID-19}

Ferritin, a universal iron-binding molecule, is responsible for the storage of iron in a biologically active form [83, 84]. Hyperferritinemia syndrome (HFS) is a spectrum of disorders characterized by excessive levels of serum ferritin, which includes macrophage activation syndrome (MAS), adult Still's disease, septic shock, and multiple organ dysfunction (MOD) [84]. The etiology of HFS depends on the degree of elevation of serum ferritin (mild/ moderate/or severe). Severe elevation, seen in HFS, is mainly triggered by viral infection $[85,86]$. Similarities between COVID-19 and HFS have recently been noticed. Gomez-Pastora et al. stated that there was elevated serum ferritin (1.5-3.5 times higher) found in all severely-ill COVID-19 patients on admission, and when comparing the ferritin levels of survivors vs. nonsurvivors, the latter had levels of serum ferritin 3-4 times higher [87]. Ruscitti et al. mentions that COVID19 shares similar pathogenic mechanisms, clinical picture, and outcomes as HFS, also maintaining ferritin levels in both pathologies has been associated with reduced mortality [2]. The similarities between HFS and COVID-19 have been outlined in Tables 1 and 2 [88]. Although high serum ferritin levels can occur in different types of pathologies, making it a non-specific marker, it should be noted that the degree of elevated serum ferritin tends to be higher when more etiologies of HFS are present [85]. This raises the question, could elevated ferritin levels indicate the prognostic outcome and point out the possible development of complications seen in COVID-19? [84, 88-90] Given the resulting increase in iron availability of these conditions, iron control as suggested may prove to be beneficial and protective [2, 85, 87, 88]. Carcillo et al. demonstrated that correction of ferritin levels in HFS patients resolved their symptoms, whereas uncorrected levels resulted in the development of serious infections [83]. Kernan et al. states that oral iron supplementation during an infection escalates the chances of mortality, while elevated serum ferritin is associated with increased viral/pathogen load, which is also demonstrated in severe COVID-19 patients $[83,88]$. It is worthy to note that hyperferritinemia is also implicated in the failure to produce antibodies post vaccination [91] (as seen in studies involving H1N1 vaccine).

This data suggests that COVID-19 may be considered a part of HFS, and its therapy may prove beneficial in the setting of COVID-19. This obervation is an 
Table 1 Clinical presentation of COVID-19 and hyperferritinemia-associated syndromes

\begin{tabular}{|c|c|c|c|c|c|}
\hline \multirow{2}{*}{$\begin{array}{l}\text { Clinical } \\
\text { presentation }\end{array}$} & \multirow{2}{*}{$\begin{array}{l}\text { COVID- } \\
19 \\
\text { mild- } \\
\text { severe }\end{array}$} & \multicolumn{4}{|c|}{ Hyperferritinemia syndromes } \\
\hline & & MAS & MOD & Still's disease & Septic shock \\
\hline Fever & + & + & + & + & + \\
\hline Fatigue & + & + & + & + & + \\
\hline Headache & + & + & + & + & + \\
\hline Rash & + & + & + & + & - \\
\hline Altered mental status & + & + & + & - & + \\
\hline Dyspnea & + & + & + & - & + \\
\hline Sore throat & + & - & - & + & - \\
\hline Joint pain/swelling & + & - & + & - & - \\
\hline
\end{tabular}

(+) Present and (-) not present (MAS) macrophage activation syndrome (MOD) multi-organ dysfunction

additional proof that optimal iron control may be protective against COVID-19.

\section{ii. The link to hepcidin}

Hepcidin is the key regulator for iron metabolism. Hepcidin binds to ferroportin, which is the iron export channel found on tissues that prevents the release of iron. Iron would fail to enter the circulation and would remain sequestered inside the cells [92, 93]. In the absence of hepcidin, ferroportin efflux of iron is uninhibited, causing release of iron into the circulation. Therefore, hepcidin determines iron availability and distribution.

As was previously mentioned, pathogens have adapted methods to acquire iron from their hosts. It is even advantageous for some to make use of already present iron-related channels and receptors to acquire this iron, including transferrin and lactoferrin receptors. A distant sequence similarity has been found by Ehsani between the SARS-Cov-2 spike protein and puffer fish hepcidin [3]. This similarity was found at the cytoplasmic tail of the spike protein. Other similarities include cysteine-rich areas on the hepcidin and spike protein, use of furin for activation, the overarching connection between IL-6 and hepcidin and COVID-19 symptoms, and similarities between COVID-19 and altitude illness-related hypoxia, the result of elevated hepcidin. It is suggested that SARS-Cov-2 is utilizing its hepcidin-like similarity to bind to ferroportin receptors on cells, and this remains to be proven. If this is the case, SARS-Cov- 2 would be strategically limiting the release of iron from the cells it infects [11]. Cavezzi et al. posit that it is this hepcidin mimicking action that could be the basis for the observed silent hypoxia seen later in severe COVID-19 patients [93]. Cavezzi also notes that the elevated hepcidin in diabetic and obese patients may be a reason for their increased risk of poor outcomes in the setting of COVID-19. Banchini et al. also found that there is an overexpression of hepcidin as well as iron overload in COVID-19 patients [94]. Overexpression of hepcidin in obese, elderly, and diabetic population is a correlating factor that may explain the increased disease severity in these patient groups. Hepcidin is further suggested as a prognostic biomarker in these patients [95].

Table 2 Laboratory and clinical abnormalities in COVID-19 and hyperferritinemia-associated syndromes [72]

\begin{tabular}{|c|c|c|c|c|c|}
\hline \multirow{2}{*}{$\begin{array}{l}\text { Laboratory/clinical } \\
\text { evaluation }\end{array}$} & \multirow{2}{*}{$\begin{array}{l}\text { COVID-19 } \\
\text { severe }\end{array}$} & \multicolumn{4}{|c|}{ Hyperferritinemia syndromes } \\
\hline & & MAS & MOD & Still's disease & Septic shock \\
\hline Hyperferritinemia & + & + & + & + & + \\
\hline Ferritin range (ng/ml) & $+(300-5000)$ & $+(>10000)$ & $+(300-5000)$ & $+(>5000)$ & $+(300-5000)$ \\
\hline Hypercytokemia & + & + & + & + & + \\
\hline Infection triggered & + & + & + & + & + \\
\hline Multi-organ involvement & + & + & + & + & + \\
\hline ARDS & + & + & + & + & + \\
\hline Low/absent NK activity & + & + & + & + & + \\
\hline ESR/CRP (high/low) & + & + & + & + & + \\
\hline Abnormal liver function & + & + & + & + & + \\
\hline
\end{tabular}

(+) Present and (-) not present (MAS) macrophage activation syndrome (MOD) multi-organ dysfunction 


\section{Medicine-based adjuvant therapeutic considerations in the setting of infection i. Iron control}

Iron chelators are very advanced medications used to prevent the accumulation of excess iron and its toxic effects, and their use has been suggested in the setting of COVID-19 [96, 97]. These drugs decrease iron availability for pathogens, resulting in their inactivation and death [98]. There are many pathogens that are inhibited by iron chelators, such as HIV, Ebola, Herpes simplex virus, TB, H. pylori, and HCV [99-101]. Examples of iron chelators include bipyridyl and desferoxamine, which are currently under clinical trial for COVID-19 patients (NCT04333550) [98, 100]. Banchini et al. suggests iron control by exploring both endogenous (insulin, heparin, and erythropoietin) and exogenous options (vitamins $\mathrm{D}$ and $\mathrm{C}$, toclizumab, carvedilol), relating to hepcidin control in the setting of COVID-19 [102]. Abbas et al. also suggest the use of iron chelators to lower disease severity in the setting of COVID-19 infection.

Lactoferrin is an iron-binding iron-chelating substance which plays a vital role in the host defense mechanisms [103, 104]. Lactoferrin is known to inhibit pseudotyped SARS-COV with an inhibitory concentration of $50 \%$. The use of lactoferrin was tested in vitro on SARS-Cov2 , which showed inhibition of viral entry via binding to the host cell surface. There is polarizing views regarding the use of iron chelators as adjuvant therapy; chelation should not be employed until there is empirical evidence of increased and relevant levels of iron. A call for antihepcidin therapy may be preferred, until actual iron dependency of the RNA coronaviruses is established [105]. There are still many questions that remain to be answered in trials with iron chelators including dosages, timing, and which iron chelator to use [106].

\section{ii. Insights from hyperferritinemia}

As mentioned before, elevated levels of serum ferritin go hand in hand with iron, so the need to maintain a moderate amount of iron in the body is essential in the therapy of hyperferritinemia, and insights from its therapy may be considered in the treatment of COVID-19 [85, 107]. Remedy used in hyperferritinemia patients is therapeutic plasma exchange (TPE) [108]. Benefits of TPE include reversing disseminated intravascular coagulation (DIC), and the removal of excess amounts of ferritin and free hemoglobin [108]. The 2010 American Society for Apheresis (ASFA) outlines the use of TPE for all hyperferritinemia syndromes $[109,110]$. TPE may prove beneficial in the setting of COVID-19 as evidenced by COVID-19 patients who recovered and were discharged after undergoing TPE therapy [101]. Iron chelators may play an additional role here as well, by decreasing the degradation of ferritin by lysosomes, decreasing the production of free radicals, and promoting the downregulation of hepcidin [82].

\section{iii. Phlebotomies and erythropoiesis}

Phlebotomy is a blood extraction procedure which decreases iron load in patients with excessive iron/ferritin blood levels [111]. With each phlebotomy, ferritin levels decrease by $30-50$ points. Tanaka et al. confirms that the use of "petit phlebotomy" is beneficial in Hepatitis- $C$ virus infected patients as it decreases the iron overload (which damages the liver and destroys its protective enzymes) [111, 112]. Phlebotomy decreases total RBC count; as a result, it activates physiological erythropoiesis, which scavenges the body for iron stores resulting in decreased iron availability for pathogens [113]. Iron depletion by phlebotomy has also been shown to reduce insulin resistance and hyperferritinemia [114]. Hadadi et al. concluded that the use of erythropoietin stimulating drugs could attenuate SARS-COV-2 via cytokine modulation, anti-apoptotic effects, and iron redistribution away from the virus [115]. The use of recombinant erythropoietin was shown to have unexplained rapid relief and viral load regression in an 80-year-old male COVID-19 patient with severe anemia. Iron-related abnormalities in patient indices suggest that iron is being depleted on an extracellular level while overloaded on an intracellular level. This is explained by the decrease in hemoglobin and significantly increased index values of serum ferritin [116].

\section{Conclusion}

The insight provided by evolutionary and genetic perspectives, points towards an iron deficiency phenotype that has prevailed throughout generations, providing protection against acute infection. By referring to previous pandemics, a connection can be seen in the general inability of some viruses to invade deeply into high prevalence IDA territories. Human biology seems to have also evolved with this goal in mind, along with cultural and sociological patterns that have upheld the iron deficient phenotype.

Humans may have adapted ways to favor iron loss, while pathogens have adapted methods to effectively acquire iron from their hosts. Coronaviruses are RNA viruses that are highly dependent on iron. Evidence that point to an overarching role of iron in COVID-19 infection includes hyperferritinemia in severe cases, similarities between COVID-19 and hyperferritinemia syndromes, and hepcidin overexpression that may also be responsible for the increased risk of disease in diabetic, obese, and elderly patients. Given this understanding, targeting iron from a therapeutic stand point may prove decisive as part of adjuvant therapy against such viruses; however, more robust evidence is needed. These 
would include the use of iron chelators, or therapy which would sequester iron away from pathogens like erythropoietin, and targeting hepcidin control through several endogenous and exogenous means via antihepcidin agents. The observation of elevated ferritin warrants their use as prognostic markers for disease progression in COVID-19 patients. More robust research is needed to link the potential of iron control and the therapy of COVID-19 patients.

Overall, low iron is theorized to mitigate infection. It should be noted that this hypothesis still requires more evidence. Namely, iron itself is necessary for immune cell proliferation, and counter evidence suggests that low iron increases the risk of some infection. What remains to be elucidated are as follows: which low iron state is conferring the protective effect?, is it overt iron deficiency anemia or covert iron deficiency without anemia? And which pathogens are affected by this low iron state? These are the questions that remain to be answered by this hypothesis. This theory ultimately suggests that evolutionary stressors have promoted genetic variations in the form of resistant alleles. If low iron mitigates infection, then the areas with high iron deficiency anemia prevalence may be protected against some types of infection, such as Sub-Saharan Africa. Therefore, to enhance this theory, further investigations are needed to determine the genetic variants responsible for iron imbalance among susceptible populations. Focus on iron indices in COVID-19 patients is also necessary to provide a clear picture of the iron metabolism of these patients before the suggestion of iron control in the clinical setting.

\section{Abbreviations}

ARDS: Acute respiratory distress syndrome; CMV: Cytomegalovirus; COVID 19: Coronavirus Disease 2019; DIC: Disseminated intravascular coagulation; HFE: High Fe2+; HFS: Hyperferritinemia syndrome; HH: Hereditary hemochromatosis; HIV: Human immunodeficiency virus; IDA: Iron deficiency anemia; PCR: Polymerase chain reaction; RNA: Ribonucleic acid; SARS-COV2: Severe Acute Respiratory Syndrome Coronavirus 2; SSA: Sub-Saharan Africa; TPE: Therapeutic plasma exchange; WRA: Women of reproductive age
\end{abstract}

\section{Acknowledgements}

None

\section{Authors' contributions}

RM and EM conceptualized the idea behind this review. RM, EM, AA, and AFA, drafted the manuscript. RM, EM, and AFA, revised the final manuscript. The authors read and approved the submitted version for publication. The authors agree to be personally accountable for the integrity and accuracy of the study.

\section{Funding}

None

Availability of data and materials

Not required

Ethics approval and consent to participate Not required
Consent for publication

Not required

\section{Competing interests}

The authors declare that they have no competing interests.

\section{Author details}

${ }^{1}$ Faculty of Medicine, Kasr al Ainy, Cairo University, Geziret Elroda, Manial, Cairo 11562, Egypt. ${ }^{2}$ Vascular Surgery Department, Cairo University Hospitals, Giza, Egypt. ${ }^{3}$ Pediatric Cardiology Department, Cairo University Hospitals, Giza, Egypt.

Received: 4 September 2020 Accepted: 20 November 2020

Published online: 16 December 2020

\section{References}

1. Kannan S, Shaik Syed Ali P, A S, K H. COVID-19 (Novel Coronavirus 2019). Eur Rev Med Pharmacol Sci 2020;24:2006-2001. https://doi.org/10.26355/eurrev.

2. Ruscitti P, Berardicurti O, Benedetto P Di, Cipriani P, lagnocco A, Shoenfeld $Y$, et al. Severe COVID-19, Another piece in the puzzle of the hyperferritinemic syndrome . an immunomodulatory perspective to alleviate the storm. Front Immunol 2020;11. https://doi.org/10.3389/fimmu.2020. 01130.

3. Ehsani S. Distant sequence similarity between hepcidin and the novel coronavirus spike glycoprotein : a potential hint at the possibility of local iron dysregulation in n.d.;arXiv: 200. https://doi.org/https://arxiv.org/ftp/ arxiv/papers/2003/2003.12191.pdf.

4. Denic S, Agarwal MM (2007) Nutritional iron deficiency: an evolutionary perspective. Nutrition 23:603-614. https://doi.org/10.1016/j.nut.2007.05.002

5. Cassat JE, Skaar EP (2013) Iron in infection and immunity. Cell Host \&microbe 13:509-519. https://doi.org/10.1016/j.chom.2013.04.010.Iron

6. Nairz M, Schroll A, Sonnweber T, Weiss G (2010) Microreview the struggle for iron - a metal at the host - pathogen interface. Cell Microbiol 12:16911702. https://doi.org/10.1111/j.1462-5822.2010.01529.x

7. Payne SM (1993) Iron acquisition in microbial pathogensis. Trends Microbiol 1:66-69

8. Drakesmith $\mathrm{H}$, Prentice A (2008) Viral infection and iron metabolism. Nat Rev Microbiol 6:541-552. https://doi.org/10.1038/nrmicro1930

9. Chang H, Bayeva M, Taiwo B, Palella FJ (2015) Short communication: high cellular iron levels are associated with increased HIV infection and replication. AIDS Res Hum Retroviruses 31:305-312. https://doi.org/10.1089/ aid.2014.0169

10. Caza M, Kronstad JW (2013) Shared and distinct mechanisms of iron acquisition by bacterial and fungal pathogens of humans. Front Cell Infect Microbiol 3. https://doi.org/10.3389/fcimb.2013.00080

11. Ganz T, Nemeth E (2015) Iron homeostasis in host defence and inflammation. Nat Rev Immunol 15:500-510. https://doi.org/10.1038/nri3863.Iron

12. Wadner K, Shell-Duncan B, McDade TW (2009) Evaulation of Iron deficiency as a nutritional adaptation to infectious disease: an evolutionary medicine perspective. Am J Hum Biol 21:172-179. https://doi.org/10.1002/ajhb.20839. Evaluation

13. Tielsch JM, Khatry SK, Stoltzfus RJ, Katz J, LeClerq SC, Adhikari R, et al. Effect of routine prophylactic supplementation with iron and folic acid on preschool child mortality in southern Nepal: community-based, clusterrandomised, placebo-controlled trial. Lancet (London, England) 2006;367: 144-52. https://doi.org/10.1016/S0140-6736(06)67963-4.

14. Athiyarath R, Shaktivel K, Abraham V, Singh D, Bondu JD, Chapla A et al (2015) Association of genetic variants with response to iron supplements in pregnancy. Genes Nutr 10:474. https://doi.org/10.1007/s12263-015-0474-2

15. Poggiali E, Andreozzi F, Nava I, Consonni D, Graziadei G, Cappellini MD (2015) The role of TMPRSS6 polymorphisms in iron deficiency anemia partially responsive to oral iron treatment. Am J Hematol 90:306-309. https://doi.org/10.1002/ajh.23929

16. Das I, Saha K, Mukhopadhyay D, Roy S, Raychaudhuri G, Chatterjee M et al (2014) Impact of iron deficiency anemia on cell-mediated and humoral immunity in children: a case control study. J Nat Sci Biol Med 5:158-163. https://doi.org/10.4103/0976-9668.127317

17. Cook JD (1999) Defining optimal body iron. Proc Nutr Soc 58:489-495 https://doi.org/10.1017/s0029665199000634

18. Camaschella C (2015) Iron-deficiency anemia. N Engl J Med 327:1832-1843. https://doi.org/10.1056/NEJMra1401038 
19. Organization WH. Worldwide prevalence of anaemia 1993-2005: WHO global database on anaemia. Geneva, Switzerland: World Health Organization; 2008. World Heal Organ 2008.

20. Kassebaum NJ, Jasrasaria R, Naghavi M, Wulf SK, Johns N, Lozano R et al (2014) A systematic analysis of global anemia burden from 1990 to 2010 Blood 123:615-625. https://doi.org/10.1182/blood-2013-06-508325.The

21. Nyakeriga AM, Troye-blomberg M, Dorfman JR, Alexander ND, Ba R, Kortok $M$ et al (2004) Iron deficiency and malaria among children living on the coast of Kenya. J Infect Dis S 190:439-447. https://doi.org/10.1086/422331

22. Clark MA, Goheen MM, Fulford A, Prentice AM, Elnagheeb MA, Patel J et al (2014) Host iron status and iron supplementation mediate susceptibility to erythrocytic stage Plasmodium falciparum. Nat Commun 5. https://doi.org/ 10.1038/ncomms5446

23. John CC (2013) Complex Interactions of HIV Infection, malaria, and iron deficiency. Clin Infect Dis 57:1635-1637. https://doi.org/10.1093/cid/cit534

24. Esan MO, Van Hensbroek MB, Nkhoma E, Musicha C, White SA, Kuile FO et al (2013) Iron Supplementation in HIV-infected Malawian children with anemia; a double-blind, randomized controlled trial. Clin Infect Dis 57:16261634. https://doi.org/10.1093/cid/cit528

25. Gangaidzo IT, Moyo VM, Mvundura E, Aggrey G, Murphree NL, Khumalo H et al (2001) Association of pulmonary tuberculosis with increased dietary iron. J Infect Dis 184:936-939. https://doi.org/10.1086/323203

26. Lounis N, Truffot-pernot C, Grosset J, Gordeuk VR, Boelaert JR. Iron and Mycobacterium tuberculosis infection. Virology 2001;20:123-126. https://doi. org/10.1016/S1386-6532(00)00136-0.

27. Sazawal S, Black RE, Ramsan M, Chwaya HM, Stoltzfus RJ, Dutta A, et al. Effects of routine prophylactic supplementation with iron and folic acid on admission to hospital and mortality in preschool children in a high malaria transmission setting : community-based, randomised, placebo-controlled trial. Lancet 2006; 367:133-143. https://doi.org/10.1016/S0140-6736(06)67962-2.

28. Oppenheimer SJ (2001) Iron and its relation to immunity and infectious disease. J Nutr 131:616-635. https://doi.org/. https://doi.org/10.1093/jn/131. 2.6165

29. Jin J, Bai P, He W, Wu F, Liu X, Han D et al (2020) Gender differences in patients with COVID-19: focus on severity and mortality. Public Health 8. https://doi.org/10.3389/fpubh.2020.00152

30. Wenham C, Smith J, Morgan R. COVID-19: the gendered impacts of the outbreak. Lancet 2020;395:846-848. https://doi.org/10.1016/S01406736(20)30526-2

31. Rosenberg R. Detecting the emergence of novel, zoonotic viruses pathogenic to humans. Cell Mol Life Sci 2015;72:1115-1125. https://doi.org/ 10.1007/s00018-014-1785-y.

32. Sharma G, Volgman AS, Michos ED (2020) Sex differences in mortality from COVID-19 pandemic: are men vulnerable and women protected? JACC Case Reports. https://doi.org/10.1016/j.jaccas.2020.04.027

33. Remuzzi A, Remuzzi G. COVID-19 and Italy: what next? Lancet (London, England) 2020;395:1225-8. https://doi.org/10.1016/S0140-6736(20)30627-9.

34. Alghamdi IG, Hussain II, Almalki SS, Algamdi MS, Algamdi MM, El-Sheemy MA (2014) The pattern of Middle East respiratory syndrome coronavirus in Saudi Arabia: a descriptive epidemiological analysis of data from the Saud Ministry of Health. Int J Gen Med 7:417-423. https://doi.org/10.2147/IJGM. S67061

35. $K D B, R A, \sqcup H, E J C, J A R$. Gender differences in the utilization of health care services. J Fam Pr 2000:147-152.

36. Chen L, Li Q, Zheng D, Jiang H, Wei Y, Zou L et al (2020) Clinical characteristics of pregnant women with Covid-19 in Wuhan. China. N Engl J Med. https://doi.org/10.1056/NEJMc2009226

37. Prospective study on prevalence of anemia of pregnant women and its outcome: a community based study. J Fam Med Prim Care 2017;6:739-743. https://doi.org/10.4103/jfmpc.jfmpc_33_17.

38. Öztürk M, Öztürk Ö, Ulubay M, Karaşahin E, Özgürtaş T, Yenen M et al (2017) Anemia prevalence at the time of pregnancy detection Gebeliğin tanısı ile birlikte saptanan anemi prevalansı. Turkish J Obstet Gynecol 14:176-180. https://doi.org/10.4274/tjod.06337

39. Cao C, Fleming MD (2016) The placenta: the forgotten essential organ of iron transport. Nutr Rev 74:421-431. https://doi.org/10.1093/nutrit/nuw009

40. Mcardle HJ, Lang C, Hayes H, Gambling L (2011) Role of the placenta in regulation of fetal iron status. Nutr Rev 69:17-22. https://doi.org/10.1111/j. 1753-4887.2011.00428.x

41. Petry N, Olofin I, Hurrell RF, Boy E, Wirth JP, Moursi M et al (2016) The proportion of anemia associated with iron deficiency in low, medium, and high human development index countries: a systematic analysis of national surveys. Nutrients 8:1-17. https://doi.org/10.3390/nu8110693

42. Delamou A, Delvaux T, Marie A, Ayadi E, Beavogui AH, Okumura J, et al. Public health impact of the 2014 - 2015 Ebola outbreak in West Africa: seizing opportunities for the future. BMJ Glob Heal 2017;2:2016-2018. https://doi.org/10.1136/bmjgh-2016-000202.

43. Elston JWT, Cartwright C, Ndumbi P, Wright J (2016) The health impact of the 2014-15 Ebola outbreak. Public Health 143:60-70. https://doi.org/10. 1016/j.puhe.2016.10.020

44. Chitungo I, Dzobo M, Hlongwa M, Dzinamarira T (2020) COVID-19: unpacking the low number of cases in Africa. Public Heal Pract 1:100038. https://doi.org/10.1016/j.puhip.2020.100038

45. Rutayisire E, Nkundimana G, Mitonga HK, Boye A, Nikwigize S (2020) What works and what does not work in response to COVID-19 prevention and control in Africa. Int J Infect Dis IJID Off Publ Int Soc Infect Dis 97:267-269. https://doi.org/10.1016/j.ijid.2020.06.024

46. Zilka O, Shah R, Li B, Pedro J, Angeli F, Griesser M et al (2017) On the mechanism of cytoprotection by Ferrostatin - 1 and Liproxstatin - 1 and the role of lipid peroxidation in ferroptotic cell death. ACS Cent Sci 3:232-243. https://doi.org/10.1021/acscentsci.7b00028

47. Gac L, Fe C (2005) The molecular genetics of haemochromatosis. Eur J Hum Genet 13:1172-1185. https://doi.org/10.1038/sj.ejhg.5201490

48. Khan FA, Fisher MA, Khakoo RA (2007) Association of hemochromatosis with infectious diseases : expanding spectrum. Int J Infect Dis 11:482-487. https://doi.org/10.1016/j.ijid.2007.04.007

49. Cardoso CS, Sousa M De. HFE, the MHC and hemochromatosis: paradigm for an extended function for MHC class I. Tissue Antigens 2003;61:263-275. https://doi.org/10.1034/j.1399-0039.2003.00065.x.

50. Bahram S, Gilfillan S, Kuhn LC, Moret R, Schulze JB, Lebeau A et al (1999) Experimental hemochromatosis due to MHC class I HFE deficiency: immune status and iron metabolism. Proc Natl Acad Sci 96:13312-13317. https://doi. org/10.1073/pnas.96.23.13312

51. Ben-arieh SV, Zimerman B, Smorodinsky NI, Yaacubovicz M, Schechter C, Bacik I, et al. Human cytomegalovirus Protein US2 interferes with the expression of human HFE, a nonclassical class I major histocompatibility complex molecule that regulates iron homeostasis. J Virol 2001;75:1055710562. https://doi.org/10.1128/JVI.75.21.10557.

52. Arieh SV, Laham N, Schechter C, Yewdell JW, Coligan JE, Ehrlich R (2002) A single viral protein HCMV US2 affects antigen presentation and intracellular iron homeostasis by degradation of classical HLA class I and HFE molecules. Blood 101:2858-2864. https://doi.org/10.1182/blood-2002-07-2158. Supported

53. Pittman KJ, Glover LC, Wang L, Ko DC (2016) The legacy of past pandemics: common human mutations that protect against infectious disease. PLoS Pathog 12:e1005680-e1005680. https://doi.org/10.1371/journal.ppat.1005680

54. Fumagalli M, Sironi M, Pozzoli U, Ferrer-Admetlla A, Pattini L, Nielsen R (2011) Signatures of environmental genetic adaptation pinpoint pathogens as the main selective pressure through human evolution. PLoS Genet 7: e1002355. https://doi.org/10.1371/journal.pgen.1002355

55. Barber MF, Elde NC (2014) Escape from bacterial iron piracy through rapid evolution of transferrin. Science 346:1362-1366. https://doi.org/10.1126/ science.1259329

56. Prentice AM, Bah A, Jallow MW, Jallow AT, Sanyang S, Sise EA, et al. Respiratory infections drive hepcidin-mediated blockade of iron absorption leading to iron deficiency anemia in African children. Sci Adv 2019;5: eaav9020. https://doi.org/10.1126/sciadv.aav9020.

57. Prentice AM (2008) Iron metabolism, malaria, and other infections: what is all the fuss about? J Nutr 138:2537-2541. https://doi.org/10.3945/jn.108. 098806

58. Ramachandran P, Perisetti A, Kathirvelu B, Gajendran M, Ghanta S, Onukogu I, et al. Low morbidity and mortality with COVID-19 in sickle cell disease: a single center experience. EJHaem 2020;n/a. https://doi.org/10.1002/jha2.87.

59. Davies S, Henthorn J, Brozović M (1983) Iron deficiency in sickle cell anaemia. J Clin Pathol 36:1012-1015. https://doi.org/10.1136/jcp.36.9.1012

60. Koduri PR (2003) Iron in sickle cell disease: a review why less is better. Am J Hematol 73:59-63. https://doi.org/10.1002/ajh.10313

61. Jallow MW, Cerami C, Clark TG, Prentice AM, Campino S (2020) Differences in the frequency of genetic variants associated with iron imbalance among global populations. PLoS One 15:e0235141

62. Dean M, Carrington M, Winkler C, Huttley GA, Smith MW, Allikmets R et al (1996) Genetic restriction of HIV-1 infection and progression to AIDS by a 
deletion allele of the CKR5 structural gene. Hemophilia Growth and Development Study, Multicenter AIDS Cohort Study, Multicenter Hemophilia Cohort Study, San Francisco City Cohort, ALIVE. Science 273:1856-1862. https://doi.org/10.1126/science.273.5283.1856

63. Sabeti PC, Walsh E, Schaffner SF, Varilly P, Fry B, Hutcheson HB et al (2005) The case for selection at CCR5-Delta32. PLoS Biol 3:e378. https://doi.org/10. 1371/journal.pbio.0030378

64. Lim JK, Louie CY, Glaser C, Jean C, Johnson B, Johnson H et al (2008) Genetic deficiency of chemokine receptor CCR5 is a strong risk factor for symptomatic West Nile virus infection: a meta-analysis of 4 cohorts in the US epidemic. J Infect Dis 197:262-265. https://doi.org/10.1086/524691

65. DiMaggio C, Klein M, Berry C, Frangos S (2020) Black/African American Communities are at highest risk of COVID-19: spatial modeling of New York City ZIP Code-level testing results. Ann Epidemiol 51:7-13. https://doi.org/ 10.1016/j.annepidem.2020.08.012

66. AbdelMassih A, Ye J, Elhussieny N, Shulqamy M, Fouda R, Saeed R et al (2020) Single cell sequencing unraveling genetic basis of shared immunologic switch between severe COVID-19 and obesity. Obes Med. https://doi.org/10.1016/j.obmed.2020.100303

67. Genovese G, Friedman DJ, Ross MD, Lecordier L, Uzureau P, Freedman BI et al (2010) Association of trypanolytic ApoL1 variants with kidney disease in African Americans. Science 329:841-845. https://doi.org/10.1126/science. 1193032

68. Old FY, Neveu M, Benner SA, Kim H (2013) The "Strong" RNA world hypothesis: fifty years old. Astrobiology 13:39403. https://doi.org/10.1089/ast. 2012.0868

69. Johnston WK, Johnston WK, Unrau PJ, Lawrence MS, Glasner ME, Bartel DP RNA-Catalyzed RNA Polymerization: accurate and general RNA-templated primer extension. Science (80- ) 2001;292:1319-25. https://doi.org/10.1126/ science.1060786.

70. Sanger HL, Klotzt G, Riesnert D, Gross HJ, Albrecht K (1976) Viroids are single-stranded covalently closed circular RNA molecules existing as highly base-paired rod-like structures. Proc Natl Acad Sci 73:3852-3856. https://doi. org/10.1073/pnas.73.11.3852

71. Diener T (1989) Circular RNAs : Relics of precellular evolution ? Proc Natl Acad Sci 86:9370-9374. https://doi.org/10.1073/pnas.86.23.9370

72. Forterre $P$. Three RNA cells for ribosomal lineages and three DNA viruses to replicate their genomes: a hypothesis for the origin of cellular domain. Proc Natl Acad Sci 2006;103:3669-3674. https://doi.org/10.1073/pnas.0510333103.

73. Carrasco-Hernandez R, Jácome R, Vidal YL, De León SP, Darwin C (2017) Are RNA viruses candidate agents for the next global pandemic? A review. ILAR J 58:343-358. https://doi.org/10.1093/ilar/ilx026

74. Schrag SJ, Rota PA, Bellini WJ (1999) Spontaneous mutation rate of measles virus: direct estimation based on mutations conferring monoclonal antibody resistance. J Virol 73:51-54

75. Eckerle LD, Becker MM, Halpin RA, Li K, Venter E, Lu X et al (2010) Infidelity of SARS-CoV Nsp14-Exonuclease mutant virus replication is revealed by complete genome sequencing. PLoS Pathog 6. https://doi.org/10.1371/ journal.ppat.1000896

76. Minskaia E, Hertzig T, Gorbalenya AE, Capanacci VCC, Canard B, Ziebuhr J (2006) Discovery of an RNA virus $3^{\prime}->5^{\prime}$ exoribonuclease that is critically involved in coronavirus RNA synthesis. Proc Natl Acad Sci 103:5108-5113. https://doi.org/10.1073/pnas.0508200103

77. Kadner RJ (2005) Regulation by iron: RNA rules the rust. J Bacteriol 187: 6870-6873. https://doi.org/10.1128/JB.187.20.6870

78. Massé E, Escorcia FE, Gottesman S (2003) Coupled degradation of a small regulatory RNA and its mRNA targets in Escherichia coli. Genet Dev 17: 2374-2383. https://doi.org/10.1101/gad.1127103.pressed

79. Davis BM, Quinones M, Pratt J, Ding Y, Waldor MK (2005) Characterization of the small untranslated RNA RyhB and its regulon in Vibrio cholerae †. J Bacteriol 187:4005-4014. https://doi.org/10.1128/JB.187.12.4005

80. Juang $\mathrm{H}-\mathrm{H}$. Modulation of iron on mitochondrial aconitase expression in human prostatic carcinoma cells. Mol Cell Biochem 2004;265:185-94. https://doi.org/10.1023/b:mcbi.0000044395.59739.1 f.

81. Shi ST, Lai MMC (2005) Viral and cellular proteins involved in coronavirus replication. Curr Top Microbiol Immunol 287:95-131. https://doi.org/10. 1007/3-540-26765-4_4

82. Abobaker A (2020) Reply: iron chelation may harm patients with COVID-19. Eur J Clin Pharmacol:1-2. https://doi.org/10.1007/s00228-020-02988-9

83. Kernan KF, Carcillo JA (2017) Hyperferritinemia and inflammation. Int Immunol 29:401-409. https://doi.org/10.1093/intimm/dxx031
84. Rosário C, Zandman-Goddard G, Meyron-Holtz EG, D'Cruz DP, Shoenfeld Y (2013) The hyperferritinemic syndrome: macrophage activation syndrome, Still's disease, septic shock and catastrophic antiphospholipid syndrome. BMC Med 11. https://doi.org/10.1186/1741-7015-11-185

85. Adams P (2008) Management of elevated serum ferritin levels. Gastroenterol Hepatol 4:333-334

86. Senjo H, Higuchi T, Okada S, Takahashi O (2018) Hyperferritinemia: causes and significance in a general hospital. Hematology 23:817-822. https://doi. org/10.1080/10245332.2018.1488569

87. Jenifer Gómez-Pastora, a Mitchell Weigand, a James Kim, a Xian Wu, a Jacob Strayer, a Andre F. Palmer, a Maciej Zborowski, b Mark Yazer c and JJC. Hyperferritinemia in critically ill COVID-19 patients - is ferritin the product of inflammation or a pathogenic mediator? 2020. https://doi.org/10.1016/j.cca. 2020.06.033

88. Colafrancesco S, Alessandri C, Conti F, Priori R (2020) COVID-19 gone bad: a new character in the spectrum of the hyperferritinemic syndrome? Autoimmun Rev 102573. https://doi.org/10.1016/j.autrev.2020.102573

89. Kyriazopoulou E, Leventogiannis K, Norrby-Teglund A, Dimopoulos G, Pantazi A, Orfanos SE et al (2017) Macrophage activation-like syndrome: an immunological entity associated with rapid progression to death in sepsis. BMC Med 15:1-10. https://doi.org/10.1186/s12916-017-0930-5

90. Zaim S, Chong JH, Sankaranarayanan V, Harky A (2020) COVI-19 and multiorgan response. Curr Probl Cardiol 100618. https:/doi.org/10.1016/j.cpcardiol.2020.100618

91. Eiselt J, Kielberger L, Sedlácková T, Racek J, Pazdiora P (2010) High ferritin, but not hepcidin, is associated with a poor immune response to an influenza vaccine in hemodialysis patients. Nephron Clin Pract 115:c147c153. https://doi.org/10.1159/000312878

92. Rossi E (2005) Hepcidin - the iron regulatory hormone hepcidin. Clin Biochem 26:47-49

93. Cavezzi A, Troiani E, Corrrao S (2020) COVID-19: hemoglobin, iron, and hypoxia beyond inflammation. A narrative review. Clin Pract 10:1271. https://doi.org/10.4081/cp.2020.1271

94. Banchini F, Vallisa D, Maniscalco P, Capelli P, Banchini D. Iron overload and hepcidin overexpression could play a key role in COVID infection, and may explain vulnerability in elderly, diabetics, and obese patients. vol. 91. 2020. https://doi.org/10.23750/abm.v91i3.9826.

95. Zhou C, Chen Y, Ji Y, He X, Xue D (2020) Increased serum levels of hepcidin and ferritin are associated with severity of COVID-19. Med Sci Monit 26: e926178-e926178. https://doi.org/10.12659/MSM.926178

96. Dalamaga M, Karampela I, Mantzoros CS (2020) Could iron chelators prove to be useful as an adjunct to COVID-19 treatment regimens? Metabolism 108. https://doi.org/10.1016/j.metabol.2020.154260

97. Mobarra N, Shanaki M, Ehteram H, Nasiri H, Sahmani M, Saeidi M et al (2016) A review on iron chelators in treatment of iron overload syndromes. Int J Hematol Stem Cell Res 10:239-247

98. Liu W, Zhang S, Nekhai S, Liu S (2020) Depriving iron supply to the virus represents a promising adjuvant therapeutic against viral survival. Curr Clin Microbiol Reports. https://doi.org/10.1007/s40588-020-00140-w

99. Chaolin Huang, Yeming Wang, Xingwang Li, Lili Ren, Jianping Zhao, Yi Hu, Li Zhang, Guohui Fan, Jiuyang Xu, Xiaoying Gu, Zhenshun Cheng, Ting Yu, Jiaan Xia, Yuan Wei, Wenjuan Wu, Xuelei Xie, Wen Yin, Hui Li, Min Liu, Yan Xiao, Hong Gao, Li Guo, Jungang Xie BC. Clinical features of patients infected with 2019 novel coronavirus in Wuhan, China. Lancet (London, England) 2020;395(10223).

100. Romeo AM, Christen L, Niles EG, Kosman DJ (2001) Intracellular chelation of iron by bipyridyl inhibits DNA virus replication: ribonucleotide reductase maturation as a probe of intracellular iron pools. J Biol Chem 276:2430124308. https://doi.org/10.1074/jbc.M010806200

101. Meyer D (2006) Iron chelation as therapy for HIV and mycobacterium tuberculosis co-infection under conditions of iron overload. Curr Pharm Des 12:1943-1947. https://doi.org/10.2174/138161206777442164

102. Banchini F, Vallisa D, Maniscalco P, Capelli P (2020) Iron overload and hepcidin overexpression could play a key role in COVID infection, and may explain vulnerability in elderly, diabetics, and obese. Acta Biomed 91. https://doi.org/10.23750/abm.v91i3.9826

103. Chang R, Bun Ng T, Sun W-Z, Chang chang R. Lactoferrin as potential preventative and treatment for COVID-19 2020. https://doi.org/10.22541/au. 158630054.41052564.

104. Rosa L, Cutone A, Lepanto MS, Paesano R, Valenti P (2017) Lactoferrin: a natural glycoprotein involved in iron and inflammatory homeostasis. Int J Mol Sci 18. https://doi.org/10.3390/ijms18091985 
105. Garrick MD, Ghio AJ (2020) Iron chelation may harm patients with COVID19. Eur J Clin Pharmacol:1-2. https://doi.org/10.1007/s00228-020-02987-w

106. Vlahakos VD, Marathias KP, Arkadopoulos N, Vlahakos D V. Hyperferritinemia in patients with COVID-19: an opportunity for iron chelation? Artif Organs 2020;n/a. https://doi.org/10.1111/aor.13812.

107. Halstead ES, Rajasekaran S, Fitzgerald JC, Weiss SL (2016) Hyperferritinemic sepsis: an opportunity for earlier diagnosis and intervention? Front Pediatr 4 2-5. https://doi.org/10.3389/fped.2016.00077

108. Dogan L, Kaya D, Sarikaya T, Zengin R, Dincer A, Ozkan Akinci I, et al. Plasmapheresis treatment in COVID-19-related autoimmune meningoencephalitis: case series. Brain Behav Immun 2020:0-1. https://doi. org/10.1016/j.bbi.2020.05.022

109. Wang Y, Jiang W, He Q, Wang C, Wang B, Zhou P et al (2020) A retrospective cohort study of methylprednisolone therapy in severe patients with COVID-19 pneumonia. Signal Transduct Target Ther 5:9-11. https://doi. org/10.1038/s41392-020-0158-2

110. Lin GG (2012) Scott JG. The role of plasmapharesis in the critically III 100: 130-134. https://doi.org/10.1016/j.pestbp.2011.02.012.Investigations

111. Tanaka N, Horiuchi A, Yamaura T, Komatsu M, Yokoyama T, Okaniwa S et al (2009) Efficacy and safety of addition of minor bloodletting (petit phlebotomy) in hepatitis $C$ virus-infected patients receiving regular glycyrrhizin injections. J Gastroenterol 44:577-582. https://doi.org/10.1007/ s00535-009-0034- $x$

112. Holsworth RE, Cho YI, Weidman JJ, Sloop GD, St. Cyr JA. Cardiovascular benefits of phlebotomy: Relationship to changes in hemorheological variables. Perfus (United Kingdom) 2014;29:102-116. https://doi.org/10.1177/ 0267659113505637.

113. Miller JL, Tanno T (2010) Iron loading and overloading due to ineffective erythropoiesis. Adv Hematol 2010. https://doi.org/10.1155/2010/358283

114. Valenti L, Fracanzani AL, Dongiovanni P, Bugianesi, Elisabetta Marchesini G, Manzini P, Vanni E, et al. (2007) Iron depletion by phlebotomy improves insulin resistance in patients with nonalcoholic fatty liver disease and hyperferritinemia. Am J Gastroenterol 102:1251-1258

115. Hadadi A, Mortezazadeh M, Kolahdouzan K, Alavian G (2020) Does recombinant human erythropoietin administration in critically ill COVID-19 patients have miraculous therapeutic effects? J Med Virol:1-4 https://doi. org/10.1002/jmv.25839

116. Abbas AM, Mostafa AS (2020) Use of iron chelators to reduce the severity of COVID-19. Thromb Haemost 4:1042

\section{Publisher's Note}

Springer Nature remains neutral with regard to jurisdictional claims in published maps and institutional affiliations.

\section{Submit your manuscript to a SpringerOpen ${ }^{\circ}$ journal and benefit from:}

- Convenient online submission

- Rigorous peer review

- Open access: articles freely available online

- High visibility within the field

- Retaining the copyright to your article

Submit your next manuscript at $\boldsymbol{\nabla}$ springeropen.com 